\section{In Vitro Tensile Strength of Luting Cements on Metallic Substrate}

\author{
Iara A. Orsi ${ }^{1}$, Fernando K. Varoli ${ }^{2}$, Carlos H.P. Pieroni ${ }^{3}$, Marly C.C.G. Ferreira ${ }^{4}$,
} Eduardo Borie ${ }^{1,5}$

\begin{abstract}
The aim of this study was to determine the tensile strength of crowns cemented on metallic substrate with four different types of luting agents. Twenty human maxillary molars with similar diameters were selected and prepared to receive metallic core castings ( $\mathrm{Cu}-\mathrm{Al}$ ). After cementation and preparation the cores were measured and the area of crown's portion was calculated. The teeth were divided into four groups based on the luting agent used to cement the crowns: zinc phosphate cement; glass ionomer cement; resin cement Rely X; and resin cement Panavia F. The teeth with the crowns cemented were subjected to thermocycling and later to the tensile strength test using universal testing machine with a load cell of $200 \mathrm{kgf}$ and a crosshead speed of $0.5 \mathrm{~mm} / \mathrm{min}$. The load required to dislodge the crowns was recorded and converted to $\mathrm{MPa} / \mathrm{mm}^{2}$. Data were subjected to Kruskal-Wallis analysis with a significance level of $1 \%$. Panavia F showed significantly higher retention in core casts $\left(3.067 \mathrm{MPa} / \mathrm{mm}^{2}\right)$, when compared with the other cements. Rely X showed a mean retention value of $1.877 \mathrm{MPa} / \mathrm{mm}^{2}$ and the zinc phosphate cement with $1.155 \mathrm{MPa} / \mathrm{mm}^{2}$. Glass ionomer cement $\left(0.884 \mathrm{MPa} / \mathrm{mm}^{2}\right)$ exhibited the lowest tensile strength value. Crowns cemented with Panavia $\mathrm{F}$ on cast metallic posts and cores presented higher tensile strength. The glass ionomer cement showed the lowest tensile strength among all the cements studied.
\end{abstract}

\author{
'Department of Dental Materials and \\ Prosthesis, School of Dentistry of \\ Ribeirão Preto, USP - University of \\ São Paulo, Ribeirão Preto, SP, Brazil \\ ${ }^{2}$ Private Practice, Limeira, SP, Brazil \\ ${ }^{3}$ Private Practice, Jundiaí, SP, Brazil \\ ${ }^{4}$ Private Practice, Franca, SP, Brazil \\ ${ }^{5}$ School of Dentistry, Universidad \\ de La Frontera, Temuco, Chile
}

Correspondence: Profa. Dra. lara Augusta Orsi, Avenida do Café, S/N, 14040-904 Ribeirão Preto, SP, Brazil. Tel: +55-16-36024796. e-mail: iaraorsi@forp. usp.br, iara_orsi@yahoo.com

\section{Introduction}

During function in the oral environment, prostheses are subjected to repeated loads and temperature changes (1), with luting agents maintaining their integrity during the stress transfer of fixed partial prostheses for teeth support. This stress may cause deformation, ranging from retrievable elastic deformation, to permanent plastic deformation and fracture of the luting agent (2).

The ideal cement should provide a reliable bond between different subtracts and compressive and tensile fracture strengths during clinical use (3).

Adhesive and nonadhesive cements have widely been used for cementing metallic crowns for a long time (4). There exist a wide variety of dental luting cements with different mechanical and biological features, with zinc phosphate, conventional glass ionomer, polycarboxylate, resin-modified glass ionomer and resin cements for dental purpose. Despite the success of zinc phosphate cement has been well documented in the literature $(3,5)$, some authors $(5,6)$ have reported the superiority of resin cements in relation to tensile strength, when compared with zinc phosphate, conventional glass ionomer and resin-modified glass ionomer cements (7). However, the literature has no studies assessing luting agents cemented to metallic substrate.

The aim of this in vitro study was to determine the tensile strength of crowns cemented on metallic substrate with four different kinds of cements.

\section{Material and Methods}

Twenty human maxillary molars with similar diameters and dimensions were selected and stored in distilled water at room temperature during 21 days (Ethical Committee approval \#2002.1.234.58.7).

The coronal portions of the roots were sectioned at cervical level, specifically $2 \mathrm{~mm}$ from coronal to the cementoenamel junction with a carborundum disc assembled to a handpiece at low speed. The residual pulp tissue was removed with Gates Glidden drills (Dentsply/ Maillefer, Ballaigues, Switzerland) \#1 and 2, and the post spaces were prepared with Pesso reamer (Dentsply/ Maillefer) \#2 and 3. Root canals were molded for casting direct technique using Duralay acrylic resin (Reliance Dental Mfg. Co., Worth, IL, U.S.A.) and the resin patterns were cast in $\mathrm{Cu}$-Al alloy. The cast metal post-cores were adapted to the roots and all of them cemented with zinc phosphate cement (Vigodent, Rio de Janeiro, RJ, Brazil). The coronal core portion was prepared for cast crowns with diamond-tapered flat-end bur \#3071 (KG Sorensen, Barueri, SP, Brazil) with high-speed instrumentation under water spray cooling. The cervical margin with a uniform $0.5-\mathrm{mm}$-wide shoulder was prepared in healthy tooth structure and beveled with a flame-shaped bur \#3113 (KG Sorensen, Cotia, SP, Brazil), and the shoulder beveled finishing lines were finished with H246UF multilaminated bur (Komet Brazil, Santo André, SP, Brazil). A dental surveyor was used to vertically teeth position on the 
polyvinyl chloride (PVC) rings and the root portion of each tooth was fixed with autopolymerizing acrylic resin (Clássico Dental Products, São Paulo, SP, Brazil) $2 \mathrm{~mm}$ below the cementoenamel junction.

The impression of each tooth was made with polyether material (3M ESPE, Seefeld, Germany) following manufacturer's instruction in single copings of autopolymerizing acrylic resins copings (Clássico Dental Products). The impressions were poured with type IV dental stone (Dentsply, Petrópolis, RJ, Brazil) to construct the dies, and subsequently, waxing was performed. The wax patterns were adapted to the teeth fixed in the PVC rings with aim of a dental surveyor for the sprue placement in the central occlusal portion of the pattern, at long axes of the tooth (Fig. 1A). The wax patterns were embedded in dental investment (Bego; Bremen, Germany) prepared according to manufacturer's instructions and cast with $\mathrm{Ni}-\mathrm{Cr}$ alloy (Wiron 99; Bego). After cooling at room temperature, the castings were divested, cleaned, and sandblasted with aluminum oxide $(50 \mu \mathrm{m})$ and fitted on their respective prepared teeth. The sprues with $10 \mathrm{~mm}$ were placed parallel through the long axes of the teeth to position the dental elements properly with the crowns cemented in the universal testing machine and perform the tensile test.

A piece of aluminum foil was cut with a scalpel blade and adapted on each tooth preparation, until the cervical limit, with the aid of an amalgam burnisher. The foils were removed, cut and opened on sheet of papers to determine the limits (Fig. 1B). Then, the sheets of paper with bounded surfaces were carried to a planimeter (Bender \& Hobein, München, Germany) to calculate the area of cementation (Fig. 1C).

The teeth were divided into four groups based on the cements used: zinc phosphate cement (Vigodent, Rio de Janeiro, RJ, Brazil); glass ionomer cement (Ketac-Cem, 3M-ESPE, Seefeld, Germany); resin cement Rely X (3M Dental Products, St. Paul, USA); and resin cement Panavia F (Kuraray, Umeda, Japan). The core metallic casts of Rely $\mathrm{X}$ and Panavia $\mathrm{F}$ were sandblasted with a microetcher (Bio Art Dental Products Sao Carlos, SP, Brazil) and aluminum oxide $(50 \mu \mathrm{m})$ prior cementation. The cast crowns were placed in an ultrasonic bath with distilled water and then with isopropyl alcohol for 5 min to remove impurities.

The cements were proportioned and manipulated according to the manufacturers' instructions and inserted into the inner portion of the castings. The teeth positioned on PVC rings were placed in a loading device for crown cementation with a static vertical load of $5 \mathrm{kgf}$ for 10 min. The cement excess was removed after initial set.

After cementation procedure, the teeth were immersed in distilled water at $37{ }^{\circ} \mathrm{C}$ for $48 \mathrm{~h}$ and subjected to a
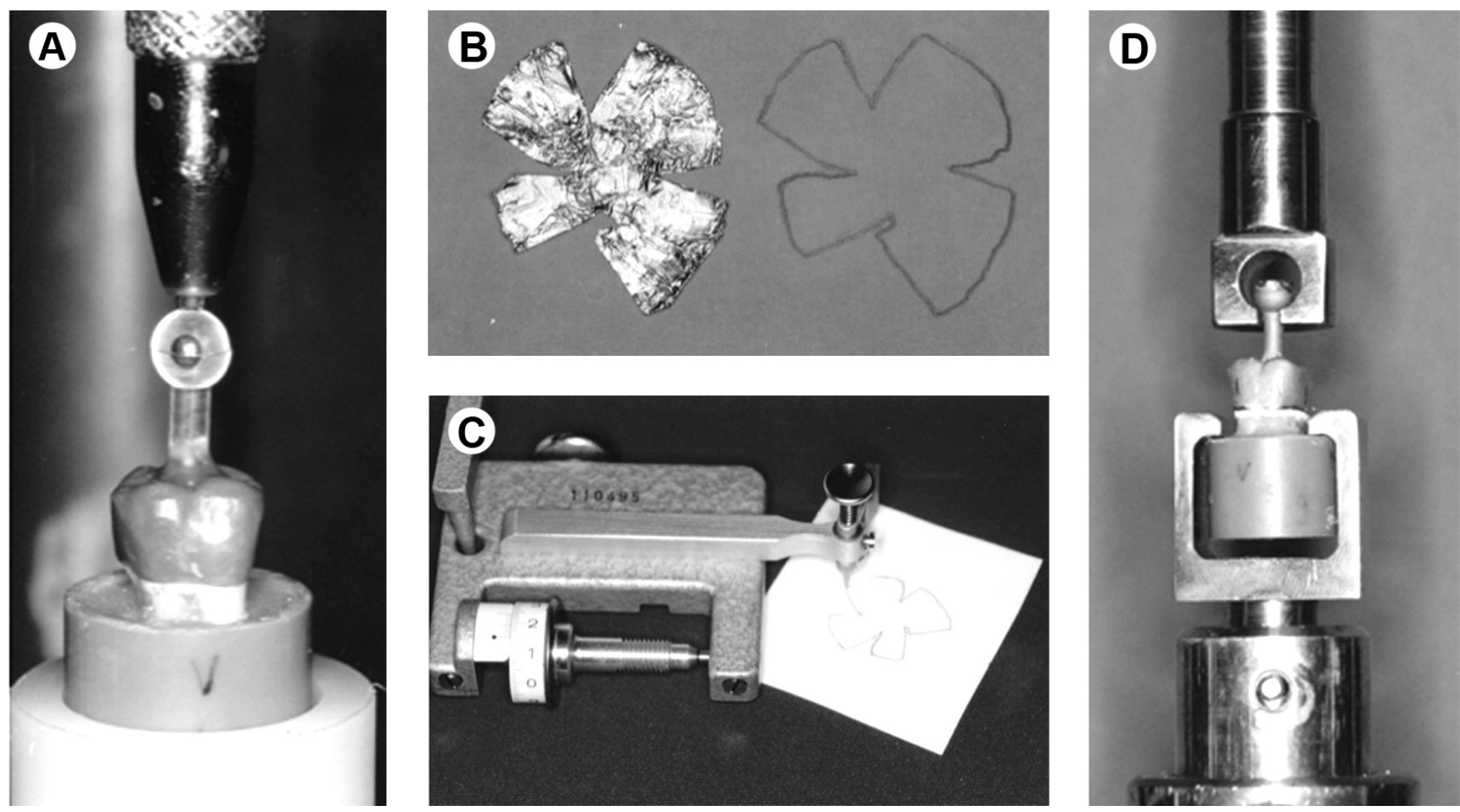

Figure 1. A: Sprue on the occlusal crown surface. B: Limits of the cementation area. C: Measurement of area in the planimeter. D: Tensile strength assay. 
500 -cycle thermocycling regimen in water bath at $5{ }^{\circ} \mathrm{C}$ and $55^{\circ} \mathrm{C}$. After, the teeth were stored in distilled water at $37^{\circ} \mathrm{C}$ for $48 \mathrm{~h}$.

After this period, the tooth-cemented crown set was subjected to tensile strength test using a universal testing machine (EMIC, São José dos Pinhais, PR, Brazil) (Fig. 1D), with a load cell of $200 \mathrm{kgf}$ and a crosshead speed of 0.5 $\mathrm{mm} / \mathrm{min}$. The load required to dislodge the crown was recorded, and the data provided in kgf unit were converted to $\mathrm{MPa} / \mathrm{mm}^{2}$ using the following equation:

$\mathrm{T}=\mathrm{F} \times \mathrm{AG} / \mathrm{TA}$, where

$T=$ Tensile strength; $F=$ Load for displacement of the crown $(\mathrm{kgf}) ; A G=$ Acceleration of gravity $(9.81 \mathrm{~m} / \mathrm{s}) ; \mathrm{TA}$ $=$ Total area of tooth preparation.

Data were subjected to Kruskal-Wallis statistic test with a significance level of $1 \%$ probability.

\section{Results}

The tensile strength values for each dental luting agent and the statistical comparison is shown in Table 1.

The resin cements presented the highest tensile

\section{Discussion}

The luting agents more commonly used in crown cementation are zinc phosphate, glass ionomer, resinmodified glass ionomer and resin cement.

Dental restorations are subjected to repetitive dynamic loading with a combination of compressive and tensile stresses on the restoration during mastication and parafunction (8). For clinical success is important to evaluate the tensile strength of luting agents due many of these materials are brittle, being susceptible to failures (9).

The behavior of each of them on the dental surface

Table 1. Mean tensile strength values $\left(\mathrm{MPa} / \mathrm{mm}^{2}\right)$ for each luting agent and statistical comparison

\begin{tabular}{ll}
\hline Luting agents & Means \\
\hline Panavia F & $3.067 \mathrm{a}$ \\
Rely X & $1.877 \mathrm{~b}$ \\
Zinc Phosphate & $1.155 \mathrm{c}$ \\
Ketac-Cem & $0.884 \mathrm{~d}$ \\
\hline
\end{tabular}

*Different letters indicate statistically significant difference (KruskalWallis test, $\mathrm{p}<0.05$ ). is well known, but the tensile strength behavior of these cements in metal cast cores has not yet been reported in the literature. Generally, removing cemented crowns by pulling them along the long axis of preparation with an increasing statically loaded model has set the retentive strength of dental cements (10).

In the current study, the highest retention values were observed in Panavia F cement, $3.06 \mathrm{MPa} / \mathrm{mm}^{2}$ (Table 1). These results are in accordance with those of other studies $(6,7,11,12)$, which showed that resin cements support a greater tensile strength than zinc phosphate and glass ionomer. This highest value of Panavia $F$ resin cement could be explained because this luting agent exhibit better imbrication on to the irregularities of the metal surfaces. Also, this cement was found to show increased bond strength to metal alloy when adhered to an oxide-rich surface; e.g., if sandblasted with aluminum oxide (13). The sandblasting increases the surface area for bonding and decreases the surface tension, which allows a better wetting by the resin cement (14). Previous studies $(13,15,16)$ have shown that Rely X presented more tensile strength than zinc phosphate and glass ionomer cement, and statistically significant difference was shown only between Rely X and Ketac Cem. However, Rely X showed half of the tensile strength of Panavia $F$, and this result is in contrast to that observed by Palacios et al. (17).

The physical properties of resin luting agents may range by the differences composition in relation to the type and amount of monomer, in addition to the type, size and amount of filler particles (18), this is the quantity and quality of polymeric and inorganic phases in combination with the setting mechanisms (9).

Panavia $F$ is a dual luting agent with lower values of sorption and solubility due the increased conversion degree. This increased factor tends to decrease the sorption and solubility, because exists a decrease of residual monomer and an increase of chemical bond (at the inner) matrix that will help to impede the water diffusion (19).

In contrast, a low value of tensile strength had been observed for glass ionomer and zinc phosphate cement when compared with the resin luting agents. Zinc phosphate cement has no adhesive properties, depends of mechanical interlocking over the substrates irregularities (20), being also brittle and susceptible to tensile failures (9). Glass ionomer cement has lower tensile strength and fracture resistance, being susceptible to moisture at the beginning stage of setting process (21). Rosenstiel et al. (22) stated that solubility plays an important role in the success of the cements to prevent failure in the retention.

The numerical values of tensile strength of zinc phosphate were higher than those of glass ionomer cements, which agree with the results previous reports 
$(6,23)$.

The lowest retention value $\left(0.88 \mathrm{MPa} / \mathrm{mm}^{2}\right)$ was observed for Ketac Cem cement, which is a nonconventional glass ionomer cement that contains no covalent cross-linking being undergo to water degradation (24). Comparisons of Weibull moduli for each cement, performed by Mitchell et al. (5) showed that exists a lower probability of failure in zinc phosphate cement subjected at very low load when compared to conventional glass ionomer.

Probably this result occurred because the glass ionomer are susceptible to crazing and water degradation and dehydration during the initial setting reaction, observing that the resulting microcracks may begin and facilitate the crack propagation within the cement matrix (24).

These low values for glass ionomer were in accordance with the findings of earlier studies $(6,23)$. According to Mitchell et al. (5), there exist some doubts about the cohesive ability of glass ionomer cement to resists high stresses generated during contraction on setting in vitro when is present in thin layers between two substrates.

In the present study, tensile strength was evaluated considering the prepared tooth surface area. This procedure is very important to determine the real tensile strength because when the prepared tooth area is increased higher retention values are expected.

According to Heintze (25), stump height and convergence angles of prepared teeth, and the luting agents are the most important factors that influence crown dislodgement. The retention of artificial crowns varies according to the mechanical properties of luting agents, geometric relationship of prepared tooth surface and definitive restoration, because these factors may influence the stress distribution within the cement layer and at surface-cement interface (7).

Within the limitations of this study, it may be concluded that crowns cemented with Panavia $F$ on the metallic cast core presented higher tensile strength. Although there is no established value of load that can be considered ideal for clinical success, Panavia F showed the best retention value to metal cast cores, which could be important when additional crown retention is used for tooth rehabilitation. In addition, the glass ionomer cement showed the lowest tensile strength among the cements studied.

\section{Resumo}

0 objetivo deste estudo foi determinar a resistência à tração de coroas cimentadas em substrato metálico com quatro diferentes tipos de agentes cimentantes. Vinte molares humanos maxilares com diâmetros semelhantes foram selecionados e preparados para receberem núcleos metálicos fundidos (Cu-Al). Após cimentação e preparo, os núcleos foram mensurados e a área da porção coronária foi calculada. Os dentes foram divididos em quatro grupos baseados no agente cimentante utilizado para cimentar as coroas: cimento de fosfato de zinco; cimento de vidro ionômero; cimento resinoso Rely X; e cimento resinoso Panavia F. Os dentes com as coroas cimentadas foram submetidos a termociclagem e logo à prova de resistência à tração usando a máquina de ensaios universal com uma célula de carga de $200 \mathrm{kgf}$ e uma velocidade de $0,5 \mathrm{~mm} / \mathrm{min}$. A carga necessária para deslocar as coroas foi registrada e convertida a $\mathrm{MPa} / \mathrm{mm}^{2}$. Os dados foram submetidos ao análise de Kruskal-Wallis com um nivel de significância de 1\%. Panavia F mostrou uma retenção significativamente maior nos núcleos fundidos $\left(3,067 \mathrm{MPa} / \mathrm{mm}^{2}\right)$, quando comparados com os outros cimentos. Rely $X$ mostrou um valor médio de retenção de $1,877 \mathrm{MPa} / \mathrm{mm}^{2}$ e o cimento de fosfato de zinco com 1,155 MPa/ $\mathrm{mm}^{2}$. 0 cimento de vidro ionômero $\left(0,884 \mathrm{MPa} / \mathrm{mm}^{2}\right)$ exibiu o menor valor de resistência à tração. As coroas cimentadas com Panavia $\mathrm{F}$ nos pinos e núcleos metálicos fundidos apresentaram maior resistência à tração. 0 cimento de ionômero de vidro mostrou o menor valor de resistência à tração entre todos os cimentos estudados

\section{References}

1. Ishijima T, Caputo AA, Mito R. Adhesion of resin to casting alloys. J Prosthet Dent 1992;67:445-449.

2. Li ZC, White SN. Mechanical properties of dental luting cements. J Prosthet Dent 1999;81:597-609.

3. Diaz-Arnold AM, Vargas MA, Haselton DR. Current status of luting agents for fixed prosthodontics. J Prosthet Dent 1999;81:135-141.

4. Yilmaz $Y$, Dalmis A, Gurbuz T, Simsek S. Retentive force and microleakage of stainless steel crowns cemented with three different luting agents. Dent Mater J 2004;23:577-584.

5. Mitchell CA, Abbariki M, Orr JF. The influence of luting cement on the probabilities of survival and modes of failure of cast full-coverage crowns. Dent Mater 2000;16:198-206.

6. Zidan 0 and Ferguson GC. The retention of complete crowns prepared with three different tapers and luted with four different cements. J Prosthet Dent 2003;89:565-571.

7. Ayad MF, Rosenstiel SF, Salama M. Influence of tooth surface roughness and type of cement on retention of complete cast crowns. J Prosthet Dent 1997;77:116-121.

8. Uy JN, Lian JN, Nicholls JI, Tan KB. Load-fatigue performance of gold crowns luted with resin cements. J Prosthet Dent 2006; 95:315-322.

9. White $\mathrm{SN}, \mathrm{Yu}$ Z. Compressive and diametral tensile strengths of current adhesive luting agents. J Prosthet Dent 1993;69:568-572.

10. Junge T, Nicholls JI, Phillips KM, Libman WJ. Load fatigue of compromised teeth: a comparison of 3 luting cements. Int J Prosthodont 1998;11:558-564.

11. Hill EE and Lott J. A clinically focused discussion of luting materials. Aust Dent J 2011;56:67-76.

12. Cano-Batalla J, Soliva-Garriga J, Campillo-Funollet $M$, MunozViveros CA, Giner-Tarrida L. Influence of abutment height and surface roughness on in vitro retention of three luting agents. Int $J$ Oral Maxillofac Implants 2012;27:36-41.

13. Abreu A, Loza MA, Elias A, Mukhopadhyay S, Rueggeberg FA. Effect of metal type and surface treatment on in vitro tensile strength of copings cemented to minimally retentive preparations. J Prosthet Dent, 2007;98:199-207.

14. Chung $\mathrm{K}-\mathrm{H}$, Hwang $\mathrm{Y}-\mathrm{C}$. Bonding strengths of porcelain repair systems with various surface treatments. J Prosthet Dent 1997; 78: 267-274.

15. Johnson $\mathrm{GH}$, Lepe $X$, Zhang $\mathrm{H}$, Wataha JC. Retention of metal-ceramic crowns with contemporary dental cements. J Am Dent Assoc 2009; 140:1125-1136.

16. Tolidis K, Papadogiannis D, Papadogiannis Y, Gerasimou P. Dynamic and static mechanical analysis of resin luting cements. J Mech Behav Biomed Mater 2012; 6:1-8.

17. Palacios RP, Johnson GH, Phillips KM, Raigrodski AJ. Retention of zirconium oxide ceramic crowns with three types of cement. J 
Prosthet Dent 2006:96:104-114.

18. Pace LL, Hummel SK, Marker VA, Bolouri A. Comparison of the flexural strength of five adhesive resin cements. J Prosthodont 2007; 6:18-24.

19. Walker MP, Spencer P, Eick JD. Effect of simulated resin-bonded fixed partial denture clinical conditions on resin cement mechanical properties. J Oral Rehabil 2003;30:837-846.

20. Pilo R, Lewinstein I, Ratzon T, Cardash HS, Brosh T. The influence of dentin and/or metal surface treatment on the retention of cemented crowns in teeth with an increased taper. Dent Mater 2008,24:10581064.

21. Piwowarczyk A, Lauer H-C, Sorensen JA. In vitro shear bond strength of cementing agents to fixed prosthodontic restorative materials. J
Prosthet Dent 2004:92:265-273.

22. Rosenstiel SF, Land MF, Crispin BJ. Dental luting agents: A review of the current literature. J Prosthet Dent 1998;80:280-301.

23. Gorodovsky $\mathrm{S}$ and Zidan 0 . Retentive strength, disintegration, and marginal quality of luting cements. J Prosthet Dent 1992; 68:269-274.

24. Knobloch LA, Kerby RE, Seghi R, Berlin JS, Lee JS. Fracture toughness of resin-based luting cements. J Prosthet Dent 2000;83:204-209.

25. Heintze SD. Clinical relevance of tests on bond strength, microleakage and marginal adaptation. Dent Mater 2013;29:59-84.

Received July 13, 2013 Accepted March 17, 2014 